\title{
HOCAMIZ PROF. DR. SELIM TOLKUN ARAMIZDAN AYRILDI
}

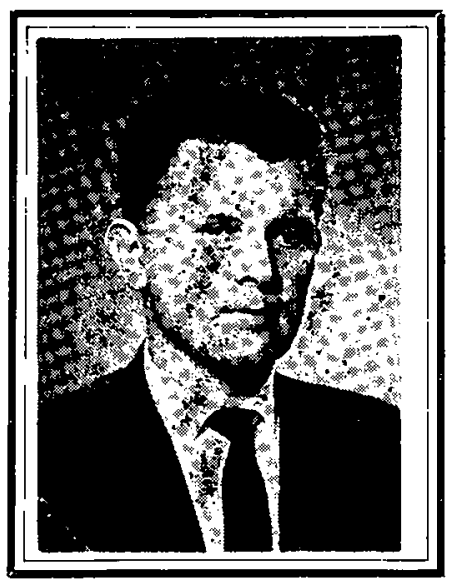

Hocamız Prof. Dr. Selim Tolkun 13.5.1975 günü 36 yıllık bir hizmet süresinden sonra, kendi isteği ile emekliyc ayrılmıştır. Mesleğimize uzun yıllar Veteriner Hekim, uzman, Doktor ve Öğretim üyesi yetiştiren bu klymetli büyüğümüz vcrimli olabileceği bir çağda sağlığı nedeniyle, çok sevdiği Fakültemizden ve özcllikle branşı olan Şirurji dalından ayrılması bizleri üzmüştür.

Sayın Prof. Dr. Selim Tolkun 14 Temmuz 1916 yilinda Bursada doğmuştur. Babasının adı Mustafa, annesinin adı da Sıdıka dır. Ilk, orta ve lise öğrenimini Bursada tamamlamış 1935 yılında Veteriner Fakültesine kaydolmuş ve 1939 da Mezun olmuştur.

Hocamızın Mesleğine ilk ayni yıl Bursa Merkez Veterineri iken başlamıştır. 1941 yılında vatani görevini tamamlayan Tolkun 1942 senesinde Ikinci Dünya Savaşı nedeniyle birkez daha askerlik vazifesi yapmiş ve 1944 de terhis edilmiştir.

Profesör Tolkun'un Fakülteye Asistan olarak girişi 1942 tarihine raslamaktadır. Bu günden itibaren hocamız A.Ü. Veteriner Şirurji Kürsüsünde aralıksız hizmet görmüştür. 
Sayın Tolkun Tarım, Sağllk ve Sosyal Yardım Bakanlıklarının özcl izinleriyle İ.Uं. Tıb Fakültesi Radiyoloji Kürsüsünde iki yıl süreyle ihtisas yapmıs, ayrica Ord. Prof. Dr. Osman Çubukçunun yönetiminde Fizik tedavi kurslarına da katılmıştır. Bu bakımdan memleketimizde Veteriner Radiyolojinin ilk kurucularndandır.

1947 de Doktorasin veren Tolkun 1949 vilinda da bir yıl sürcyle. Ingiltercye gönderilmiştir. Burada da Genel radiyoloji ve İzotoplar üzcrinde incelemelerde bulunan tolkun 1953 de Doçentliğe yükselmiştir. 1956 yllinda 18 ay süre ilc Viyanaya gitmiştir. Tolkun ayni yerde gene Radiyoloji ile ilgili araştırmalarda bulunmuştur. 1963 de 3 ay Amerikada kalan hocamı ayni yılın sonunda Bağdat Veteriner Fakültesinde Şirurji Dersleri vermiştir. 1968 de Profesör olan hocamız birçok uzmanlık, doktora ve Doçentlik jürilerinde bulunmuşmuştur. Yayımlanmış olarak 20 ye yakın Araştırma yazıları vardır.

1975 de kendi isteği ile cmekliyc ayrılan hocamız evli olup bir erkek çocuğu vardır.

Sayın Tolkun'a bundan sonraki yaşammnda sağlık mutluluk ve uzun ömürler dileğiyle yazımıza son vermek isterken vc henüz yazımız baskıya gireceği bir sırada sayın hocamızı 7. Nisan 1976 günü kaybetmiş bulunduk. Muhterem hocamıza tanrıdan rahmet ve kederli ailesiyle tüm meslektaşlarma baş sağlığı dileriz. 